\title{
BREVE ANÁLISE DA INSTRUÇÃO PROBATÓRIA DO JUIZ CRIMINAL BRASILEIRO SOB A ÉGIDE DO SISTEMA ACUSATÓRIO
}

\section{BRIEF ANALYSIS OF THE PROBATION INSTRUCTION OF THE BRAZILIAN CRIMINAL JUDGE UNDER THE EGIS OF THE ACCUSATORY SYSTEM}

Ana Luiza Policani Freitas ${ }^{i}$

Resumo: O presente trabalho traz uma análise do juiz criminal brasileiro no curso da instrução probatória e sua atuação instrutória sob a égide do sistema penal acusatório, com uma leitura constitucional adotada no País após a promulgação da Constituição Cidadã de 1988. Será exposto o sistema penal acusatório, inquisitório e misto assim como as controvérsias doutrinárias em relação ao seu núcleo fundante com base na gestão da prova. A seguir, será abordada a questão da prova no sistema acusatório, assim como sua concepção dos ditames deste sistema, as funções conferidas ao magistrado na fase da instrução probatória e a problemática do cabimento dos poderes instrutórios do juiz e os princípios relacionados à gestão da prova. Insta destacar a impossibilidade de atribuição da iniciativa instrutória para o magistrado no sistema acusatório, favorecendo o Ministério Público que é um órgão competente e estruturado que possui o ônus da acusação, e a Defesa, apesar de não possuir a mesma "paridade de armas" do Parquet. No entanto, a Magna Carta brasileira que consagra tal sistema, por força da sua supremacia conforme a hierarquia das leis, deve ser respeitada junto à legislação processual penal atinente à atuação instrutória do juiz, isto é, assegurando os direitos e garantias fundamentais do acusado. 
Palavras-chave: Sistemas Processuais. Sistema Acusatório. Atuação do Juiz Criminal. Instrução Probatória. Resquícios Inquisitórios.

Abstract: This work brings an analysis of the Brazilian Criminal Judge in the course of evidential instruction and it's instructor action under the accusatory criminal system with constitutional understanding adopted in the country after the promulgation of the civil constitution of 1988. The Accusatory, Inquisitorial and mixed Criminal Systems will be demonstrated as the doctrinal controversies related to their core with basis on evidence management. Following, the subject of evidence in the accusatory system will be addressed, as its conception under the rules in this system, the roles given to the magistrate during the evidence production phase and the problems arisen from allowing the judge to produce them and the principles related to evidence management. It is important to mention that it is the Prosecutor's Office role to gather evidence and not the magistrate's, since the defense has no "Equality of arms" when it comes to gathering evidence. However, the Brazilian Magna Carta, which includes such system, must be respected together with the criminal law procedures under the judge's tutelage due its supremacy in the hierarchy of laws, safekeeping the defendant's fundamental rights.

Keywords: Procedural Systems. Accusatory System. Proceedings of the Criminal Judge. Probatorio Instruction. Inquisitorial Requests.

\section{INTRODUÇÃO}

O Processo Penal Brasileiro adotou o sistema acusatório como efetivação dos Direitos e Garantias Fundamentais previstos na Constituição Federal como da Tutela Jurisdicional (art. 50, XXXV), do Devido Processo Legal (art. 50, LIV), também conhecido como "regras do jogo", da garantia do acesso à justiça (art. 50, LXXIV), Da garantia do juiz natural (art. $5^{\circ}, \mathrm{XXXVII} \mathrm{e} \mathrm{LIII),} \mathrm{Do} \mathrm{tratamento} \mathrm{paritário} \mathrm{das} \mathrm{partes} \mathrm{(art.} 5^{\circ}$, caput e I), Da ampla defesa (art. 50, LV, LVI e LXII), Da publicidade dos atos processuais e motivação dos atos decisórios (art. 93, IX) e da presunção da inocência (art. $\left.5^{\circ}, \mathrm{LVII}\right)$.

Entretanto, há discussão doutrinária no que tange à sua limitação, classificando o sistema brasileiro contemporâneo como sistema misto, 
por conter uma fase preliminar secreta (fase pré-processual no inquérito policial), não garantindo por exemplo o contraditório e ampla defesa, característicos de um sistema inquisitório e acusatório na fase processual.

Alguns defendem que o sistema apenas possui resquícios inquisitivos, sendo o mais evidente o art. 156 do CPP, o qual prevê os poderes instrutórios do juiz.

Neste contexto, podemos verificar na atual realidade social brasileira a crise política e financeira, o aumento da criminalidade, o clamor pela punição e a publicidade dos atos instrutórios na qual o magistrado atua no curso do processo penal, em que é deduzida pretensão condenatória, diligenciando a busca do material probatório. Esse é o exemplo do que está ocorrendo com a atual Operação Lava-Jato.

Ao longo deste trabalho, analisaremos a atuação do juiz no curso da instrução probatória do processo penal brasileiro (sua atuação instrutória) sob a égide do sistema acusatório, a fim de averiguar a eventual compatibilidade entre tal sistema e a outorga de poderes instrutórios ao juiz e seu aspecto inquisitório.

\section{DO SISTEMA PENAL INQUISITÓRIO, ACUSATÓRIO E MISTO}

A noção de sistema processual é conceituada pela doutrina como um conjunto de princípios e regras constitucionais, com respaldo no momento político de cada estado. Tais sistemas têm por objeto estabelecer parâmetros a serem seguidos para a aplicação do Direito Penal a cada caso concreto. O Estado, como detentor do poder, deve efetivar a aplicação mediante processo que, via de regra, possui duas formas: inquisitiva ou acusatória. No Estado Democrático de Direito, o sistema acusatório é considerado uma garantia do cidadão contra o poder estatal; já no Estado totalitário há supressão de direitos e garantias individuais, que é onde o sistema inquisitivo encontra respaldo.

Vale observar que, com a variação histórica do processo penal ao longo da história, sua estrutura serve como parâmetro de elementos autoritários ou democráticos da Constituição vigente.

Desde a Grécia e Roma até os dias atuais, verifica-se o surgimento de três tipos de sistemas processuais: inquisitivo, acusatório e misto, os quais não se desenvolveram de forma contínua. Na Roma antiga e na Grécia já era utilizado o sistema acusatório, predominando até o século XII, sendo posteriormente substituído pelo inquisitorial que prevaleceu até o 
final do século XVIII, onde predominava o absolutismo. Essa mudança ocorreu devido ao conjunto sociopolítico vigente em cada época e lugar. Interessante ressaltar que esses tipos de sistemas foram utilizados em um mesmo momento histórico. Hoje há quem defenda que ainda existem ambas as formas de sistemas processuais, apesar da incompatibilidade do sistema inquisitorial com os direitos e garantias individuais dos cidadãos, que no Direito Brasileiro se inspirou na Declaração dos Direitos do Homem e do Cidadão de 1789 (Revolução Francesa) que, consagrados no âmbito da Carta Magna, são nomeados de direitos fundamentais. De acordo com Rogerio Greco (2016), a doutrina internacionalista reza que os direitos humanos são aqueles inerentes a toda pessoa humana e são vinculados ao jusnaturalismo. Quando tais direitos são positivados em âmbito internacional são denominados "Direitos do Homem". Se no âmbito interno consagrados por uma Constituição são chamados de "Direitos Fundamentais".

Por isso, o estudo histórico e teórico dos três sistemas possui grande importância para a determinação dos limites da atuação instrutória do juiz criminal, razão pela qual passaremos a analisá-los nos itens subsequentes.

\subsection{Do sistema inquisitório}

Em sua origem, o sistema inquisitório caracteriza-se pela concentração das funções de acusar, defender e julgar nas mãos do juiz inquisidor inexistindo, portanto, a imparcialidade. Em virtude desta centralização de poderes é que tal sistema, historicamente, esteve associado a estruturas políticas igualmente centralizadas dos estados absolutistas, aperfeiçoando-se no Direito Canônico.

Nessas ordens políticas, em nome do Estado soberano, se minimizam ou ignoram os mais elementares direitos do acusado, o que denota o motivo por que o imputado é visto não como sujeito, mas como mero objeto da inquisição. O magistrado era o centro do processo, atuando como órgão que investiga e que julga, não dependendo das provas trazidas aos autos pelas partes, utilizando, tão somente, sua livre convicção.

Os primeiros traços inquisitórios ocorreram na monarquia romana, quando vigorava o procedimento da cognitio, no qual não havia limita- 
ções ao poder do magistrado para utilizar sua livre convicção. Durante o Império Romano, o processo inquisitório desenvolveu-se em caráter subsidiário ao acusatório sob a forma da cognitio extra ordinem, com os procedimentos de ofício para os delitos públicos, neles incluídos os crimes de lesa majestade, em que a parte ofendida se identificava com o Estado Soberano, portanto, classificado como um crime mais grave com punição de execução.

O apogeu do sistema inquisitório ocorreu no período canônico durante a Idade Média, com a chamado Tribunal da Santa Inquisição, ou Santo Ofício, quando se instituiu a prática de controle severo das doutrinas heréticas - assim denominadas todas aquelas que afrontassem ou colocassem em dúvida os mandamentos da Igreja Católica, conforme previa um dos principais documentos, na época o Manual dos Inquisidores, redigido, em 1376, pelo dominicano Nicolau Eymerich, e revisto e ampliado por Francisco de la Peña em 1578. A doutrina inquisitorial era uma verdade, uma verdade absoluta que não podia ser contestada. Os indivíduos que a questionassem eram considerados hereges que, de acordo com Beccaria (2015), os crimes de lesa majestade foram postos na classe dos grandes crimes, porque são mais prejudiciais à sociedade.

A gravidade atribuída ao delito de heresia era motivo para o julgador (juiz-ator), frente a um fato típico, proceder e perquirir a prova de ofício, dando origem ao processo por investigação, bastando para sua instauração a existência de boatos (alguém disse ou fez algo contra a Fé) ou numa denúncia ex officio, ambas de forma secreta, escritas sem admitir contraditório e ampla defesa. Neste processo instaurado, há uma relação linear entre juiz e réu, que passa a ser mero objeto de investigação.

A heresia era um crime que se escondia na alma do réu e sua prova era obtida pela confissão, utilizada pela Igreja representando tanto expiação do pecado, como o reconhecimento de seu poder de autoridade, razão pela qual, no sistema da prova tarifada característico do modelo inquisitório, ela era tida como a rainha das provas, sendo suficiente para a condenação.

Caso o réu não confessasse, utilizava-se da tortura no corpo físico do acusado, o qual era objeto do suplício em nome das ordálias, que, segundo Foucalt, eram os "juízos de Deus", diante dos quais o acusado pela prática de um crime era submetido a torturas como, por exemplo, a simulação de afogamento, a roda, a tenaz de ferro candente e, se não sobrevivesse, "Deus não estaria com ele". Com isso era convencido da culpa, 
pois Deus não o livraria da morte" além da prisão cautelar. Se condenado, o réu era levado a praça pública onde era lida sua sentença condenatória e, após, o carrasco, ou iniciava o "espetáculo" no qual o condenado era queimado vivo, esquartejado por cavalos amarrados em cada um de seus membros e puxados para os quatro cantos, enforcamento ou a roda entre os mais conhecidos.

O sistema inquisitório predominou na Europa até o final do século XVIII (combatido pelas ideias iluministas) e erradicado no início do século XIX em que os Tribunais do Santo Ofício foram definitivamente abolidos em Portugal (1821) e Espanha (1834), priorizando o Estado laico, momento que houve a Revolução Francesa com a sua consequente Declaração dos Direitos do Homem e do Cidadão (1789), valorizando o ser humano e sua dignidade, removendo as características de modelo inquisitório e abolicionista.

\subsection{Do sistema acusatório}

O sistema penal acusatório se originou na Grécia antiga, onde, nos delitos "públicos" era facultado ao ofendido ou a qualquer cidadão do povo convocar o Tribunal, ao qual não cabia qualquer busca de elementos de convicção, competindo exclusivamente às partes a prova de suas alegações.

Posteriormente, se desenvolveu na República Romana (accusatio), onde ninguém podia ser levado a juízo sem uma acusação (nemo in iudicium tradetur sine accusatione). Nesse sistema, predominava a ideia do contraditório, na qual, era vedada qualquer iniciativa instrutória ao juiz. Predominavam a publicidade e a oralidade, e a absolvição acarretava sanção contra o acusador que agisse de forma temerária ou caluniosa.

Com a centralização da soberania na figura do Imperador, o sistema acusatório se mostrou insuficiente à coibição dos delitos, além de ocasionar, com frequência, os inconvenientes de uma persecução inspirada pela vingança. Por tal razão, os magistrados foram ampliando suas atribuições, inclusive aquelas antes reservadas aos particulares, até cumularem em um mesmo órgão do Estado as funções de acusar e julgar.

Com isso, prevaleceu o modelo processual que permitia a iniciativa de qualquer cidadão (accusatio), prevalecendo por muito tempo o procedimento penal de ofício, que perdurou até o período de Diocleciano (Imperador Caio Aurélio Valério Diócles Diocleciano). 
Após a queda do Império Romano, o sistema acusatório ressurgiu com base no antigo processo penal germânico, confundindo-se, nas primeiras jurisdições bárbaras, com os ritos das ordálias e dos duelos judiciais, além de consolidar-se, no mundo anglo-saxão, com o adversary system.

Tal sistema é o ideal almejado por todos os Estados Democráticos de Direito, atentando-se para a imparcialidade do julgador, eficácia do contraditório e do respeito às regras do Devido Processo Legal (regras do jogo) sob a luz da Constituição. Possui como característica a separação entre juiz e partes, devendo, assim, se manter ao longo do processo, para garantir a imparcialidade do magistrado que obtinha sua posição fundada no ne procedat iudex ex officio, além de garantir que a gestão das provas esteja nas mãos das partes (juiz-espectador) e a efetivação do contraditório.

Nesse sentido, Luigi Ferrajoli (2014, p. 453), defende que entre todos os elementos constitutivos do modelo teórico acusatório "o mais importante, por ser estrutural e logicamente pressuposto de todos os outros, indubitavelmente é a separação entre juiz e acusação".

No que tange à produção de provas, Aury Lopes Jr. (2017, p. 44) salienta que é incompatível com o sistema acusatório, também violando o contraditório e fulminando a imparcialidade, destacando as práticas de atos probatórios previstas no art. 156 do CPP e dos atos instrutórios, como por exemplo, a decretação de ofício da prisão preventiva (art. 311 do (PP), da busca e apreensão (art. 242 do CPP), a condenação do acusado sem pedido do Ministério Público, violando o princípio da correlação (art. 385 do CPP).

Não obstante, cabe ao Ministério Público (art. 129 da CF), que é órgão acusatório público oficial e independente do Judiciário, o ônus de acusar e assim produzir as provas em cada caso concreto, com fito de manter a separação entre as funções de acusar e julgar ao longo de todo o processo, mantendo as regras do devido processo legal, da garantia do juiz natural e do contraditório (art. $5^{\circ}, \mathrm{LV}$, da CF).

Finalizando a análise desse sistema, não pode ser esquecida a figura do acusado, que, no processo acusatório, é considerado sujeito de direitos, fazendo jus à possibilidade de resistir à acusação, razão pela qual impera o princípio do contraditório, previsto na Carta Magna. Logo, a defesa deve possuir a mesma paridade conferida ao Ministério Público, com iguais oportunidades no processo. Como garantia do acusado, o princípio 
da presunção de inocência (art. $5^{\circ}, \mathrm{LVII}, \mathrm{CF}$ ), motivo pelo qual a liberdade do acusado no curso do processo é a regra geral e a prisão, exceção. $\mathrm{Na}$ valoração das provas, domina o sistema do livre convencimento, não havendo mais hierarquia entre aquelas (antes da reforma de 2008, havia hierarquia entre as provas).

\subsection{Do sistema misto}

Após as ideias iluministas do século XVIII, que criticavam o sistema absolutista e suas atrocidades e a eclosão da Revolução Francesa de 1789, objetivava-se um sistema processual acusatório aderindo formas semeIhantes às desenvolvidas na Roma Imperial e na Inglaterra.

Entretanto, o ideal revolucionário conflitou com tradições culturais inquisitórias fixadas há séculos, que, ao longo do tempo, os diplomas legais revolucionários foram substituídos por outros, que mantiveram características do sistema inquisitório, mescladas com outras típicas do acusatório, dando origem ao sistema misto, também chamado de reformado ou napoleônico.

O sistema misto foi consagrado pelo Código de Instrução Criminal francês de 1808 (Code d'Instruction Criminelle), ou Código Napoleônico, durante o império de Napoleão Bonaparte (1799 -1815) que, durante o seu auge, no século XIX, foi difundido nas demais legislações europeias, que, com sua expansão, dominava quase toda a Europa Ocidental.

Tal sistema caracteriza-se pela divisão do processo em duas fases: a fase pré-processual de caráter inquisitório e a fase processual de caráter acusatório na qual o Ministério Público possui o ônus de acusar.

Tal sistema possui duras críticas em relação a impossibilidade de classificação de sua estrutura como um verdadeiro sistema por haver um reducionismo, pois todos os sistemas são mistos, visto que os modelos puros são apenas modelos históricos.

Nesse sentido, Aury Lopes Jr. (2017) aduz que, por todos os sistemas serem mistos, se faz necessário analisar qual seu fundamento (núcleo fundante) para definir o predomínio de sua estrutura inquisitória ou acusatória, ou seja, se seu princípio formador é inquisitivo - gestão das provas nas mãos do magistrado ou acusatório - cabendo às partes posicionamento ao qual este trabalho se filiará. 


\section{DA GESTÃO DA PROVA NO SISTEMA ACUSATÓRIO}

A prova é conceituada como toda tentativa de se atrelar à exatidão dos fatos passados, cuja finalidade é demonstrar a "verdade" (suposta verdade real) para convencer o juiz, sob o crivo do contraditório.

Para Luigi Ferrajoli (2014, p. 44), "a verdade 'certa', 'objetiva' ou 'absoluta' representa sempre a expressão de um ideal inalcançável", deduzindo que a ideia "de que se pode conseguir e asseverar uma verdade objetiva ou absolutamente certa é, na realidade, uma ingenuidade epistemológica."

No mesmo sentido, Eugênio Pacelli de Oliveira, em seu Curso de Processo Penal (2005, p. 281-282), reza que a verdade real, além de ser inadequada, "pois que esta diz respeito à realidade do já ocorrido, à realidade histórica", também "pode revelar uma aproximação muito pouco recomendável com um passado que deixou marcas indeléveis no processo penal antigo, particularmente no sistema inquisitório da Idade Média".

Nessa busca da verdade real, houve a disseminação de uma "cultura inquisitiva", na qual as mais diversas práticas probatórias tirânicas e desumanas foram legitimadas "pela nobreza de seus propósitos: a verdade", sendo esta uma verdade absoluta, conforme o Manual dos Inquisidores. Com isso, deixava-se a gestão da prova a cargo do magistrado (juiz-ator/inquisidor), que podia buscar o material probatório de acordo com sua vontade.

Por isso, a verdade real existente no processo não passa de algo inalcançável e inatingível e é um dos resquícios da inquisitoriedade mantida como instrumento de dominação e legitimação a justificar qualquer procedimento, inclusive no processo penal contemporâneo, que aplica os postulados do sistema acusatório.

Ferrajoli (2014) aduz que a verdade perseguida no sistema penal acusatório trata-se de uma verdade formal, a qual deve ser adquirida, como qualquer pesquisa empírica, "através do procedimento por prova e erro", de forma que a principal garantia de sua consecução é "confiada à máxima exposição das hipóteses acusatórias à falsificação pela defesa, isto é, ao livre desenvolvimento do conflito entre as duas partes do processo". Dessa maneira, a verdade formal "não pretende ser a verdade", não sendo obtida através de procedimentos inquisitivos alheios ao processo, respeitando todas as garantias da defesa, tratando-se, portanto, 
de uma verdade processual aproximada, contingente e relativa ao estado dos conhecimentos e experiências levados a cabo na ordem das coisas de que se falam, de modo que, sempre, quando se afirma'a verdade' de uma ou de várias proposições, a única coisa que se diz é que estas são verdadeiras pelo que sabemos sobre elas.

Vale observar que o obstáculo temporal é um fator prejudicial para a concepção da verdade, pois está consolidado que o crime é um fato histórico no qual a reconstituição se baseia nos signos do suposto fato (passado) previsto na memória do narrador (autor, réu, testemunha ou vítima), podendo inclusive ser preenchido por experiências verdadeiras, mas decorrentes de outros fatos, ou até mesmo de sua própria fantasia ou imaginação.

No que tange ao convencimento, Aury Lopes Jr. (2017) apregoa que "as provas são os materiais que permitem a reconstrução histórica e sobre os quais recai a tarefa de verificação das hipóteses, com a finalidade de convencer o juiz", em que as partes trabalham a persuasão, a captura psíquica do magistrado, com a finalidade de mantê-lo "em crença". Durante o processo, o juiz constrói a sua versão do delito, motivo pelo qual a sentença por ele proferida ao final nada mais é do que um ato de crença, de fé, não tendo, portanto, a função de revelar a verdade, e esta é incerta, e não fundante. Assim, a legitimidade do poder contido na sentença decorre da observância das regras do devido processo penal ao longo do ritual judiciário. Nesse sentido, o importante é o convencimento formado a partir do que fora ingressado legalmente no processo (regido pelo sistema acusatório), devidamente legitimado na motivação da sentença.

Diante do exposto, concluímos que o processo penal possui uma finalidade retrospectiva, em que, através das provas legalmente inseridas no processo, podem-se criar condições para uma atividade recognitiva do magistrado acerca de um fato passado, com finalidade de convencê-lo e, em decorrência do conhecimento deste fato, será externado na sentença, levando o réu à condenação ou à absolvição.

\subsection{Da instrução probatória}

Vimos ao longo do processo que a atividade do magistrado é recognitiva na qual a prova inserida integra a construção do convencimento 
que será legitimado na sentença. Entre o conhecimento do magistrado (cognitio) do caso concreto e a sentença que expõe seu convencimento, há a chamada instrução probatória, que é o conjunto de atos que têm por objeto recolher as provas em que deve ser decidido o litígio.

A instrução probatória se subdivide em quatro momentos da prova: propositura (postulação), admissão, produção e valoração. O primeiro momento refere-se à postulação das provas pelas partes, seguindo-se do exame de admissão pelo juiz, que deve verificar a pertinência e a relevância das diligências requeridas. Após, ocorre a produção das provas, à qual é facultado às partes participar e assistir, em observância ao princípio do contraditório (art. $5^{\circ}, \mathrm{LV}, \mathrm{CF}$ ), e, por fim, a valoração daquelas que se encontram na sentença.

Todavia, não pode ser confundida a atuação instrutória do juiz com a iniciativa instrutória. A primeira se refere que o órgão judicial é sujeito indispensável à instrução e, além de ser o responsável pela avaliação do material nela colhido, também tem a função de impedir quaisquer violações aos direitos e garantias fundamentais, por se tratar de um limite intransponível à função recognitiva do processo. Já a segunda trata-se, segundo a doutrina, de uma faculdade do juiz buscar o material probatório de ofício, conforme prevê a parte final do art. 156 do CPP, em caso de diligências não requeridas pelas partes no momento da postulação.

Devido a esta previsão legal, há controvérsia em relação a tal possibilidade no que tange à gestão da prova no sistema acusatório, que debateremos a seguir.

\subsection{Da questão dos poderes instrutórios do juiz e os princípios processuais penais norteadores da gestão da prova}

Tendo a gestão da prova como fundamento do sistema processual penal em análise, não resta dúvidas de que a atribuição de uma ampla e irrestrita iniciativa instrutória ao juiz, prevista no art. 156 do CPP, é incompatível com o sistema acusatório. Entretanto, há quem defenda o cabimento limitado (ou subsidiário) dos poderes instrutórios ao magistrado em contraposição aos que entendem que a produção probatória de ofício confere ao juiz a posição de gestor da prova, condição impensável em tal sistema.

Os defensores dos poderes instrutórios do juiz alegam que há uma vinculação entre a produção probatória oficial com objetivo de promover 
a igualdade substancial entre os litigantes, que seria viabilizada pelo comportamento mais atuante do juiz ao longo da marcha processual. Outro argumento desta corrente é o de que a iniciativa instrutória não afetaria a imparcialidade, uma vez que o magistrado, ao empreender as diligências que entenda necessárias à elucidação da causa, não conhece, de antemão, o resultado da prova a ser produzida, assim como qual das partes será beneficiada. Ademais, os poderes instrutórios do juiz justificariam e atuariam em razão do interesse público envolvido nas demandas penais, o que impede o magistrado de se contentar com eventual deficiência da atuação instrutória desenvolvida pelos sujeitos parciais (acusação e defesa), podendo se empenhar, com o fim de chegar o mais próximo possível da "verdade" da conduta criminosa elencada no caso concreto.

Em sentido oposto, estão os doutrinadores que repelem tal ideia, equiparando-a como uma característica inquisitória especialmente quando se trata da busca por uma verdade absoluta que autoriza o magistrado a ultrapassar as restrições formais que o diferenciam das partes, atuando exaustivamente na instrução, acumulando a função de julgar e perquirir (juiz-ator) quebrando a imparcialidade e ofendendo as garantias constitucionais.

Nesse sentido, argumenta-se que a determinação probatória ex officio ocorre quando o magistrado não está convencido, hipótese em que a solução imperativa seria a absolvição do réu, de sorte que tal conduta desrespeitaria a imparcialidade, criando um desequilíbrio entre as partes.

Insta observar que a divergência de ideias referentes aos poderes instrutórios do magistrado estão relacionados com cinco princípios processuais, cuja análise será imprescindível para o esclarecimento dos contornos da gestão da prova no sistema acusatório. São eles: o princípio acusatório, a presunção de inocência (art. 50, VII, CF), o in dubio pro reo (art. $5^{\circ}, \mathrm{LVII}, \mathrm{CF}$ ), a imparcialidade judicial e o polêmico in dubio pro societate, os quais veremos a seguir.

\subsection{Do princípio acusatório}

Podemos dizer que o princípio acusatório é um princípio informador do sistema acusatório, além de ser um dos pilares do Estado Democrático de Direito, garantindo a aplicação da ampla defesa e do contraditório no processo criminal. 
Em se tratando da identificação da gestão da prova como núcleo fundante do sistema penal acusatório, faz-se mister examinar as limitações impostas pelo princípio acusatório aos poderes instrutórios do juiz no sistema por ele informado.

Tal princípio se originou do "principio actorio" que no Direito antigo relacionava-se à impossibilidade da iniciação do procedimento e do recolhimento do material processual de ofício pelo tribunal criminal.

Atualmente, o princípio acusatório compreende contornos similares que, na lição de Geraldo Prado, diz: "o princípio acusatório repercute no estatuto judicial, conferindo ao magistrado reserva da função jurisdicional" (PRADO, 2001, p. 141).

Dessa forma, o papel do juiz é de um espectador, com postura imparcial na valoração dos fatos, sendo vedada a iniciativa probatória do órgão jurisdicional, impondo a este uma equidistância das partes, competindo ao Ministério Público (art. 129 da CF), órgão estruturado e organizado, o ônus integral e exclusivo de comprovar a tese acusatória com o fim de vencer a presunção de inocência já que, do contrário, via de regra, acarretará a absolvição.

Portanto, concluímos que o magistrado que ordena a produção de material probatório não suscitado nos autos não se detém, apenas, na sua atividade de julgamento, mas, ao contrário, invade o espaço destinado às partes, às quais cabem a tarefa de requerer as provas necessárias. Ademais, o juiz que procede às diligências instrutórias não requeridas pelas partes abandona a posição de afastamento determinada pelo princípio acusatório, extrapolando os limites da reserva da função jurisdicional.

\subsection{Do princípio da presunção de inocência e do in dubio pro reu}

O princípio da presunção de inocência ou da não culpabilidade previsto no art. $5^{\circ}, \mathrm{LVII}$, da Constituição Federal é compreendido como princípio que impede a outorga de consequências jurídicas sobre o investigado ou acusado antes do trânsito em julgado da sentença criminal.

Como a exposição de motivos do nosso Código de Processo Penal venera o Código Rocco de 1930, elaborado por Vicenzo Manzini, importante destacar que, para o jurista italiano, tal princípio era considerado uma absurda ideia do empirismo francês, estabelecendo a equiparação entre os indícios que justificam a imputação e a prova da culpabilidade. Por isso, o Codex italiano não consagrou o princípio da presunção de inocência, por considerá-lo um excesso de garantismo e individualismo. 
Por se tratar de um princípio reitor do processo penal, deve ser interpretado à luz da Constituição de 88 , a qual o traz no rol de seus direitos e garantias fundamentais.

A essa presunção é atribuído duplo significado - o de dever de tratamento do imputado e o de regra de julgamento. A primeira atua em duas dimensões: a interna que exclui ou ao menos restringe ao máximo a limitação da liberdade da pessoa, utilizando as medidas cautelares, se necessário, e a externa que impõe limites à publicidade abusiva e à estigmatização do acusado. No que tange à segunda, à qual nos filiaremos, a presunção de inocência impõe que a absolvição seja critério sensato quando houver dúvida judicial, mediante o in dubio pro reo, expressando que, na dúvida, deve o juiz absolver o acusado. Ambos os princípios são aludidos pelo critério do favor rei, que consagra a limitação do modelo de Direito Penal Mínimo através da certeza e da razão.

Com isso, quando o imputado é presumidamente inocente, está desobrigado de produzir provas, uma vez que existe uma presunção que deve ser destruída pelo acusador sem que o réu ou o juiz tenha qualquer dever de contribuir nessa desconstrução, conforme Aury Lopes Jr (2017, p. 355). Trata-se, portanto, do direito ao silêncio (nemo tenetur se detegere), previsto expressamente no art. $8{ }^{\circ}, \S 2^{\circ}, " g^{\prime \prime}$, da Convenção Americana sobre Direitos Humanos (CADH), também conhecido como Pacto de São José da Costa Rica com status de norma supralegal no ordenamento jurídico brasileiro.

Vale destacar que no processo penal o Ministério Público possui o ônus substancial da prova, ou seja, deve provar a presença de todos os elementos de fato sobre os quais se funda a pretensão punitiva e também a inexistência de qualquer elemento que obste o surgimento dessa mesma pretensão, não havendo o que se falar em repartição do ônus de prova, já que a carga da prova está inteiramente nas mãos do acusador, conforme o art. 156, $1^{a}$ parte do CPP, o qual deve ser lido em consonância com a garantia constitucional da inocência prevista na Magna Carta.

Ademais, ao réu será atribuído o benefício da dúvida, porque a existência desta, quando da prolação da sentença, revela que a acusação não logrou convencer o órgão jurisdicional de que o acusado praticou uma infração penal (fato típico, ilícito e culpável), não se liberando de sua carga probatória. Neste sentido, leciona Luigi Ferrajoli:

"...se a acusação tem o ônus de descobrir hipóteses e provas e a defesa tem o direito de contraditar com contra-hi- 
póteses e contraprovas, o juiz, cujos hábitos profissionais são a imparcialidade e a dúvida, tem a tarefa de ensaiar todas as hipóteses, aceitando a acusatória só se estiver provada e não a aceitando, conforme o critério pragmático do favor rei, não só se resultar desmentida, mas também se não forem desmentidas todas as hipóteses em conflito com ela" (FERRAJOLI, 2014, p. 122).

Portanto, via de regra, a incumbência da acusação não se restringe à demonstração dos fatos alegados contra o réu, sendo necessário que a prova apresentada seja convicta acerca da autoria e materialidade da infração, e, em caso de ausência de provas, assim como dúvida pelas provas produzidas no processo, o magistrado deve optar pela absolvição e não diligenciar na obtenção de novas provas como reza a segunda parte do caput do art. 156 do CPP. Nesse contexto, os poderes instrutórios do juiz só favorecem a acusação, destacando que, para a absolvição, não há a necessidade de qualquer prova. Assim, destaca-se que, no sistema acusatório, o imputado é considerado sujeito de direitos, fazendo jus à garantia constitucional da presunção de inocência, mostrando-se inadmissível a iniciativa probatória judicial.

\subsection{Do princípio da imparcialidade do juiz}

A imparcialidade é considerada uma condição sine qua non da função jurisdicional, em outras palavras, é o princípio supremo do processo, correspondendo à posição de terceiro que o Estado-Juiz atuante como órgão supraordenado às partes.

No que tange ao âmbito criminal, a imparcialidade possui correlação com o sistema acusatório, haja vista que tal sistema exige tanto a separação das funções acusatória e decisória com uma posição equidistante do magistrado em relação às partes, como em relação à atividade probatória.

Consoante o entendimento do Tribunal Europeu de Direitos Humanos, o qual consagrou que o juiz com poderes investigatórios é incompatível com a função de julgar (esse entendimento enfrenta os resquícios inquisitórios do sistema acusatório, tendo como destaque os casos Piersak (01/10/82) e De Cubber (26/10/84). A imparcialidade pode ser subdividida em duas categorias: subjetiva e objetiva. A primeira trata de uma convicção pessoal do juiz diante de um caso específico, isto é, uma con- 
vicção presumida (pré-juízo), até demonstração em sentido contrário. Já a segunda é concernente à necessidade de existência de garantias hábeis a dissipar qualquer dúvida razoável acerca da imparcialidade do magistrado ao longo do processo. Em análise às duas categorias, insta destacar que não basta ao juiz estar subjetivamente protegido, sendo necessário também se encontrar numa situação objetiva (imparcial), porquanto a inobservância de qualquer destes aspectos acarreta "a desconfiança e a incerteza na comunidade e nas suas instituições", de acordo com a doutrina de Aury Lopes Jr. (2017, p. 65).

Em relação à diferenciação exposta, a Corte Europeia reconheceu que a concentração desta dupla função (investigar e decidir) viola as perspectivas de que o acusado seja submetido a um juiz objetivamente imparcial, ferindo o dispositivo 6.1 da Convenção Europeia para a proteção dos direitos humanos e das liberdades fundamentais (1950), e reza sobre a garantia da imparcialidade do juiz.

Seguindo o entendimento do TEDH, o Tribunal Constitucional Espanhol, na sentença 145/88, aduziu que o juiz que conduziu a instrução preliminar não poderia julgar, pois violaria a imparcialidade objetiva, isto é, aquela que deriva do objeto do processo, pois o contato direto com o sujeito passivo e com os fatos poderia provocar no ânimo do juiz-instrutor uma série de pré-juízos e impressões a favor ou contra do imputado, influenciando-o na elaboração da sentença.

Apesar das decisões se referirem à fase da investigação preliminar judicial, a qual não existe no Brasil, onde, via de regra, a investigação preliminar é presidida por uma autoridade policial, esta lógica é aplicável à instrução processual, visto que tanto os poderes investigatórios exercidos na fase pré-processual, como os poderes instrutórios desenvolvidos no processo afrontam a imparcialidade do juiz. Mais uma vez destacamos, como exemplo, o artigo 156 do CPP, que trata de um resquício inquisitório em nosso ordenamento.

Importante analisar que o argumento de que o juiz pode proceder a diligências instrutórias de ofício no âmbito criminal violaria o princípio da presunção de inocência, consubstanciada no princípio do in dubio pro reo, o qual determina a absolvição do acusado em caso de dúvida judicial, o que é inadmissível em um sistema acusatório.

Diante do exposto, verifica-se que a figura do juiz-ator (juiz-gestor da prova) reflete um resquício inquisitório no sistema acusatório brasileiro no qual o magistrado deveria se limitar às funções de garantidor e de destinatário da instrução, sendo-lhe absolutamente vedada qualquer iniciativa probatória. 
Para tanto, faz-se mister analisar as disposições do Código de Processo Penal atinentes à atuação instrutória do juiz, as quais deverão ser confrontadas com os preceitos constitucionais, com o fim de demonstrar a incompatibilidade entre os dois diplomas legislativos e as graves consequências daí advindas.

\subsection{Do polêmico "princípio in dubio pro societate"}

Mediante a atual realidade do País, podemos observar que o princípio da presunção da inocência vem perdendo prestígio em nossos tribunais, principalmente na atuação do Parquet.

No sistema acusatório, as funções se dividem entre acusador e juiz em todas as fases processuais, acarretando um efeito positivo a fim de evitar o decisionismo do magistrado, uma vez que no sistema inquisitorial ele está sempre na busca de uma verdade material, assumindo a função de inquisidor.

Como já fora abordado, o CPP ainda possui resquícios inquisitórios, possibilitando ao magistrado perseguir as provas que corroborem a acusação, de sorte que, assumindo a ideia inicial de que a denúncia é verdadeira, bastando encontrar os elementos probatórios que lhe permitam condenar. Busca-se, portanto, a culpabilidade do agente, e parte-se da premissa que ele não é inocente.

Devido ao aumento da violência e a influência midiática pela "campanha do medo", o magistrado assume a função de dar uma resposta à sociedade que, por sua vez, não pode frustrá-la com uma não-condenação, pela qual será gerado um sentimento de descrédito, em relação às instâncias responsáveis pela persecução penal, principalmente, o Poder Judiciário. O juiz inquisidor, então, não hesita em cumprir o seu papel neste "jogo", o de envidar todos os esforços para garantir uma condenação.

Nesta postura, a presunção de inocência é violada, uma vez que, se for colocada como um entrave à consecução da condenação, a presunção verdadeira é a de culpabilidade. $O$ acusado em qualquer momento do processo é visto como inocente, aplicando-se a lógica do direito processual penal do inimigo, pautada na identificação de um opositor que deve ser perseguido pelo sistema inquisitorial até a sua condenação, opondose aos princípios basilares do Estado Democrático de Direito. 
Nesse contexto, também desaparece o princípio do in dubio pro reo, consequência lógica da aplicação do princípio da presunção de inocência, uma vez que se deve ter a certeza probatória para que haja a imposição da culpabilidade. Tem ocorrido uma superação do status de inocência inicial, que deveria impor, ante a dúvida acerca da existência da autoria e/ou materialidade do delito, uma interpretação e aplicação do direito favorável ao réu, não podendo a condenação se amparar em incertezas e dúvidas.

Insta destacar que o princípio do in dubio pro societate não possui previsão constitucional e nem autorização para nenhum outro dispositivo legal, sendo incompatível com a estrutura das cargas probatórias definidas pela presunção de inocência, isto é, o ônus da prova a cargo do Estado (órgão acusador) e não do investigado (não foi o que se viu por exemplo, no caso específico do julgamento pelo juiz do Tribunal Regional Federal da $4^{a}$ Região que condenou o ex-Presidente da República, o Sr. Luiz Inácio Lula da Silva).

Infelizmente, muitos tribunais brasileiros estão negando recursos de defesa e se recusam a refutar acusações frágeis e absolver réus, muitas vezes produzindo condenações injustas, acusações sem base e prisões em massa no curso do processo. Afirmar a aplicação desse "princípio" seria dizer que, havendo dúvida de autoria ou de materialidade sobre a inocência ou a condenação do acusado(a) pela prática de uma infração penal, a decisão deverá prevalecer "em favor da sociedade" gerando, assim, incerteza e insegurança jurídica.

Acerca de tal questão, oportuna a posição de Paulo Rangel que afirma:

"...o chamado princípio do in dubio pro societate não é compatível com o Estado Democrático de Direito, onde a dúvida não pode autorizar uma acusação colocando uma pessoa no banco dos réus. (...). O Ministério Público como defensor da ordem jurídica e dos direitos individuais e sociais indisponíveis, não pode, com base na dúvida, manchar a dignidade da pessoa humana e ameaçar a liberdade de locomoção com uma acusação penal (RANGEL, 2002, p. 79)."

Em face do exposto, constata-se que o princípio do in dubio pro societate é inconstitucional, devendo a sentença condenatória remeter ao critério pragmático do in dubio pro reo para solução da incerteza processual, sendo, assim. compatível com o sistema acusatório adotado, respei- 
tando o Estado Democrático de Direito e suas presunções constitucionais, em destaque, quanto ao sistema probatório.

\section{DO SISTEMA PROCESSUAL PENAL BRASILEIRO E A ATUAÇÃO INSTRUTÓRIA DO MAGISTRADO}

O Processo Penal Brasileiro iniciou-se no período da colonização no qual o País era regido pelas Organizações Afonsinas, mesmo regime inquisitorial vigente em Portugal, o qual possuía influência do Direito Romano e caráter religioso. Em 1514, foi revogado pelas Organizações Manuelinas nas quais o tipo e a quantidade de pena eram atos discricionários do magistrado. Esta foi revogada pelo Código Sebastiânico que reunia leis separadas e de difícil interpretação. Tal código teve curta aplicação, pois, em 1580, Portugal foi submetido por Felipe II de Castela.

Em 1603, foram promulgadas as Ordenações Filipinas, que foram substituídas mais à frente, em 1832, pelo Código de Processo Criminal do Império, implementando o sistema misto e napoleônico. Essa legislação refletia ainda o Direito Medieval, em que os ricos e poderosos gozavam de privilégios, podendo, com seu poder aquisitivo, salvarem-se das sanções penais, pois, no início do século $\mathrm{XVI}$, quem recebia sentenças de morte eram principalmente índios, piratas, traficantes, hereges e invasores franceses - naquela época, a maioria da população podia ser encaixada em (pelo menos) uma dessas categorias.

Somente no período imperial, com a independência do Brasil diante de Portugal, após a outorga da Constituição de 1824, que surgiram ideais liberais substituindo as práticas do antigo sistema e organizando o Poder Judiciário do País.

Com a promulgação da Constituição de 1891 no Período Republicano, fora atribuída aos estados, a faculdade de legislar sobre o processo penal, medida que acabou prejudicando a aplicação da lei penal e o avanço do processo penal no País.

Após a promulgação da Constituição de 1934, foi restabelecida a unidade processual, passando somente à União a competência para legislar sobre o processo penal.

Em 10 de novembro de 1937, passou a vigorar no ordenamento pátrio a Constituição de 1937 também conhecida por Constituição de 
Polaca (a Constituição de 1937 foi a $4^{a}$ Constituição Brasileira e a $3^{a}$ do período republicano. Ficou conhecida como a "Constituição Polaca" por ter leis de inspiração fascista, tal qual a Carta Magna polonesa de 1935), outorgada pelo presidente Getúlio Vargas, que, na mesma data, implanta a ditadura do Estado Novo.

Nesse período foi promulgado o novo Código de Processo Penal, cujas peculiaridades veremos a seguir.

\subsection{Do sistema do Código de Processo Penal de 1941}

O Código Penal vigente foi promulgado sob a égide da Constituição dos Estados Unidos do Brasil outorgada em 1937 por Getúlio Vargas no momento subsequente à dissolução da Câmara e do Senado Federal e da revogação da Constituição de 1934, implementando-se a ditadura denominada de "Estado Novo" também conhecida como "Era Vargas". O presidente (ditador) fundamentou o golpe de Estado no dia 10 de novembro de 1937 com a comoção popular causada pelo Plano Cohen (foi um documento revelado pelo Governo Brasileiro onde continha um suposto plano para a tomada do poder pelos comunistas), com a instabilidade política gerada pela intentona comunista, com o receio de novas revoluções comunistas e os seguidos estados de sítio, que, por desrespeito à lei e à ordem, assim como aos processos democráticos, ofereciam perigo para as instituições, motivo pelo qual se exigia urgentemente à virulência dos antagonismos o reforço do poder central. Com isso, houve a promessa de um plebiscito para aprová-lo, o que na prática nunca ocorreu, instituindo assim a Ditadura Vargas, concentrando o Poder Executivo e Legislativo nas mãos do presidente que legislava por via de decretos-leis os quais ele próprio aplicava.

Da mesma forma, O Código de Processo Penal foi publicado mediante o Decreto-Lei presidencial no 3.689 de 3 de outubro de 1941, em um contexto marcado pela centralização política e pelo triunfo das ideias autoritárias crescentes no País. O Codex, como podemos observar em sua Exposição de Motivos, de autoria do Ministro Francisco Campos, foi inspirado no Código de Processo Penal italiano de 1930, concebido por Vicenzo Manzini e por Alfredo Rocco, Ministro da Justiça do Governo Italiano durante o regime fascista de Benito Mussolini, complementando as características elementares da Constituição vigente.

Dentre as medidas autoritárias adotadas no CPP foi a restrição do in dubio pro reu como previsto na antiga redação do artigo 156: 


\begin{abstract}
"A prova da alegação incumbirá a quem a fizer; mas o juiz poderá, no curso da instrução ou antes de proferir sentença, determinar, de ofício, diligências para dirimir dúvida sobre ponto relevante (BRASIL, 1941)."
\end{abstract}

Além deste artigo "destaque", o Codex possuía outros dispositivos que permitiam ao magistrado efetuar diligências probatórias sem provocação das partes como os artigos 168, 196, 209, 234 e 242 do link supracitado.

Neste sentido, a faculdade instrutória do magistrado elencada no artigo 156 é um resquício inquisitorial com respaldo na concepção de presunção de culpabilidade, apesar de não ser expressamente consagrado pelo Código, foi por ele adotado, o que se infere da própria Exposição de Motivos que o antecede, que, ao apontar as expressões "criminosos" ou "os que delínquem", deixa implícita uma vertente de que os indivíduos submetidos ao processo penal são presumidamente culpados.

Vale destacar que o critério diferenciador entre os sistemas acusatório e inquisitório é a gestão da prova, onde se constata que o art. 156 do CPP externa uma característica inquisitória, quebrando a paridade do contraditório da estrutura dialética do processo penal.

Portanto, a inquisitoriedade no processo penal brasileiro não impera apenas na fase investigativa (inquérito policial), mas também em sua fase processual propriamente dita e, por mais que vigore o sistema acusatório, a gestão da prova continua nas mãos do juiz, o que por si só basta para que se considere que o Código de Processo Penal pátrio atual ainda possua resquício inquisitório de um "Estado Policial" (sistema inquisitivo) que vigorava em sua criação.

\title{
4.2 Da consagração do sistema acusatório com a promulgação da Constituição de 1988
}

Antes de chegarmos à nova Ordem Constitucional de 1988, não podemos deixar de mencionar o período de ditadura militar vivido pelo Brasil a partir de 1964 e as alterações legislativas promovidas pelos Atos Institucionais a partir de 1967 (o mais famoso foi o Al-5), sob a égide de uma Carta Magna imposta pelo Governo Militar.

O sistema de exceção, em que parte das garantias individuais e sociais era voltada para garantir os interesses autoritários da ditadura (através de conceitos como: segurança nacional, direito de associação etc.) fez crescer, durante o processo de abertura política, em meio ao gover- 
no do general João Baptista Figueiredo (último dos militares a ocupar a Presidência da República), o anseio por uma nova Constituição Brasileira, defensora dos valores democráticos, anseio esse que se tornou uma necessidade após o fim da ditadura militar e a redemocratização do Brasil, a partir de 1985.

Em novembro de 1986 ocorreram eleições para a Assembleia Constituinte. Em fevereiro do ano seguinte, o Brasil declarava-se em moratória técnica. O descontrole econômico marcaria o final do governo Sarney, com alta da inflação em 1988 e 1989.

Durante um ano e meio, foi debatida a nova Constituição Brasileira (Constituição Cidadã), promulgada em outubro de 1988, rompendo com a lógica autoritária da Carta de 1967, evidenciando o Estado Democrático, assim como os direitos e garantias fundamentais baseados na Declaração Universal de Direitos do Homem e do Cidadão (1789).

No âmbito processual penal, a nova ordem constitucional foi notória introduzindo uma nova concepção de processo penal, instituindo um sistema de amplas garantias individuais, a começar pela afirmação da situação jurídica do indivíduo que não tiver reconhecida a sua responsabilidade por sentença penal condenatória transitada em julgado, isto é, um processo como garantia do acusado, além da justiça penal submetida à exigência de igualdade efetiva entre os litigantes.

Apesar de muitos avanços após sua promulgação, a Constituição de 88 não declarou de forma explícita qual o sistema penal fora adotado, nem mesmo trouxe uma regra capaz de anular a aplicabilidade do art. 156 do CPP.

A ausência deste posicionamento não impediu que grande parcela da doutrina brasileira se posicionasse com uma adoção implícita do sistema acusatório, com base nos dispositivos constitucionais que asseguram a privatividade do exercício da ação penal pública no Ministério Público (art. 129, I), a tutela jurisdicional (art. 50, XXXV), o devido processo legal (art. 5०, LIV), o acesso à justiça (art. 5०, LXXIV), o tratamento paritário das partes (art. $5^{\circ}$, caput e inc. I), o contraditório e a ampla defesa (art. $\left.5^{\circ}, \mathrm{LV}\right)$, a publicidade dos atos processuais, a motivação dos atos decisórios (art. 93, IX) e a presunção de inocência (art. 50, LVII) ora elencados na própria Carta.

Nesse caso, a omissão do legislador constituinte não impediria o reconhecimento constitucional do sistema acusatório, visto que a Lei 
Maior alcança situações que não foram expressamente contempladas ou detalhadas no texto, isto é, constituindo um sistema, proposição que cunha o princípio da unidade da Constituição, derivado de uma interpretação sistemática, devendo o intérprete considerar preceitos integrados num sistema interno unitário de normas e princípios.

Não obstante, na medida em que a Magna Carta opta pela tutela dos direitos fundamentais, a estrutura processual derivada destes impõe a observância do modo pelo qual é possível harmonizarem-se todos estes direitos.

Dentre os direitos e garantias fundamentais tutelados pela Constituição, merece destaque a presunção de inocência (art. $5^{\circ}$, LVII), que prevê a regra de tratamento do acusado, além da regra processual em relação ao encargo probatório, pois, partindo-se da inocência do réu, quando o acusador afirma quem praticou o fato delituoso tem o encargo de provar a sua culpa. Tal observação evidencia a adoção do sistema acusatório, visto que a presunção de inocência, em sua acepção probatória consubstanciada no princípio in dubio pro reo, impõe exclusivamente ao sujeito ativo do processo penal o ônus da prova, e quando houver dúvida, deve o juiz (a quem não deve efetuar a gestão da prova) absolver o acusado.

Em outra vertente, o doutrinador Geraldo Prado (2001) posicionase que o sistema acusatório é uma decorrência da adoção constitucional do regime democrático, onde a ideia de democracia atravessa o ambiente estrutural do processo, no qual a concepção ideológica do processo penal democrático deve respeitar o modelo dialético, reservando ao juiz a função de julgar, mas com a colaboração das partes, não devendo este efetuar a iniciativa da persecução penal.

Na mesma linha, Aury Lopes Jr. (2017) reza que a democracia é um sistema político-cultural que valoriza o indivíduo frente ao Estado, manifestando-se em todas as esferas destas relações, conduzindo à democratização do processo penal e à revalorização do homem, com o fortalecimento do sujeito passivo do processo penal. Por isso, o objetivo principal da tutela não será apenas a salvaguarda dos interesses da coletividade, mas também a tutela da liberdade processual do imputado, o respeito à sua dignidade como pessoa, como efetiva parte do processo penal, como reza Aury Lopes Jr. (2015).

Da mesma forma, outro fator que corrobora a adoção constitucional do sistema acusatório é a consagração da dignidade da pessoa 
humana como fundamento da República Federativa do Brasil previsto no art. $1^{\circ}, \mathrm{III}, \mathrm{CF}$, previsto como atributo inerente a todo ser humano, ou seja, é irrenunciável e inalienável, em que a dignidade independe das circunstâncias concretas. Com isso, verifica-se que todos (inclusive o maior dos criminosos) são iguais em dignidade, no sentido de serem reconhecidos como pessoas, razão pela qual mesmo a dignidade das pessoas que cometem ações indignas ou infames não pode ser desconsiderada.

Portanto, a adoção da dignidade da pessoa humana como um dos fundamentos da república, reforça a adoção pelo modelo acusatório, haja vista ser este o único sistema processual penal em que o acusado é respeitado como sujeito de direitos, fazendo jus às garantias (constitucionais) da presunção de inocência, do contraditório, da ampla defesa e da imparcialidade do julgador.

Nessa linha o sistema acusatório tem sido reconhecida pela recente jurisprudência do STF (RECURSO EXTRAORDINÁRIO COM AGRAVO, ARE 929149, SP, SÃO PAULO 0000929-85.2012.8.26.0172;AG.REG. NO RECURSO EXTRAORDINÁRIO COM AGRAVO: AgR ARE 895011 GO - GOIÁS 0031101-46.2002.8.09.0103); STJ (RECURSO ESPECIAL, REsp 1451192, RS 2014/0101597-4; RECURSO ESPECIAL, REsp 1622310 SP 2016/0225416-1; RECURSO ESPECIAL, REsp 1446665, RS 2014/0075054-2 e TJ/RJ (RECURSO EM SENTIDO ESTRITO; RSE 124031720088190066, RIO DE JANEIRO, VOL-

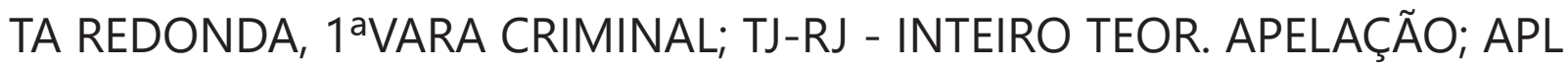
1610055320058190001, RIO DE JANEIRO, CAPITAL 37VARA CRIMINAL),como sistema constitucional adotado no ordenamento jurídico pátrio.

Assim, à luz do princípio da presunção de inocência, do regime democrático e da dignidade da pessoa humana, os quais são elementos que se concretizam num processo penal acusatório, além da necessidade de se interpretar sistematicamente a Lei Maior, concebendo-a como unidade harmônica e coerente, torna imprescindível reconhecer que a Constituição Federal de 1988 consagrou o sistema acusatório no País.

\subsection{Da reforma do CPP em 2008 e a permanência de resquícios inquisitivos}

Durante sete anos de tramitação no Congresso Nacional, três dos oito anteprojetos apresentados pela Comissão de Reforma do Código de Processo Penal ao Ministério da Justiça transformaram-se nas Leis $n^{\text {os }}$ 11.689 de 10 de junho de 2008 (modificou inteiramente o rito procedimental do júri), 11.690, de 10 de junho de 2008 (alterou o tratamento das 
provas) e 11.719 de 20 de junho de 2008 (promoveu ampla modificação nos ritos e procedimentos), efetivando as reformas do Código de Processo Penal.

No campo da distribuição dos ônus da prova, a Lei no 11.719/08 reforça a adoção do sistema acusatório, as partes como protagonistas na fase de inquirição de testemunhas, reservando-se ao magistrado uma função supletiva, de esclarecimento dos depoimentos. Nesta vertente, há um descompasso com a regra geral do art. 156 do mesmo CPP, a qual prevê uma ampla liberdade de iniciativa probatória conferida ao juiz, legitimada pelo Princípio da Verdade Real.

No que tange à atuação instrutória do juiz, destacaremos a análise da nova redação conferida pela Lei 11.690 ao artigo 156 do CPP, a qual consagra a figura do "juiz-instrutor-inquisitor", que, de ofício, na fase de investigação preliminar, ordena a produção de provas consideradas urgentes e relevantes (que bem entender), para depois, durante o processo, decidir a partir de seus próprios atos, reforçando, assim, o modelo inquisitorial que serviu de base ao processo penal dos anos quarenta com inspiração fascista.

Nesta linha, Eugênio Pacelli, considera que:

"Não cabe ao juiz tutelar a qualidade da investigação, sobretudo porque sobre ela, ressalvadas determinadas provas urgentes, não se exercerá jurisdição. O conhecimento judicial acerca do material probatório deve ser reservado à fase de prolação da sentença, quando se estará no exercício de função tipicamente jurisdicional. Antes, a coleta de material probatório, ou de convencimento, deve interessar àquele responsável pelo ajuizamento ou não da ação penal, jamais àquele que a julgará. Violação patente ao sistema acusatório (PACELLI, 2017, p. 19)."

Por isso, é verificável que a nova redação do artigo 156 do CPP, ao ampliar os poderes instrutórios do magistrado, contempla o anseio punitivo (principalmente nos dias atuais com o apoio midiático) com a falsa crença de que a criminalidade prevista na sociedade brasileira só é passível de ser resolvida com mais punição, reforçando ainda mais o caráter inquisitório do Código de Processo Penal, que continua, assim, a ter resquícios do princípio inquisitivo, se contrapondo ao sistema acusatório consagrado pela Magna Carta de 88. 
Devido à discrepância entre o sistema processual penal adotado pela legislação infraconstitucional (CPP) e a Constituição de 88, é de praxe verificar que a coexistência do sistema acusatório e inquisitório no mesmo ordenamento jurídico é inadmissível, sobretudo quando há enfoque na atuação instrutória do juiz.

Neste caso, a solução para esse conflito deve ser encontrada nos critérios de hermenêutica constitucional, os quais serão analisados a seguir.

\subsection{Da supremacia da Constituição de 88 x a legislação infraconstitucional}

A República Federativa do Brasil constitui um Estado Democrático de Direito e é constituída por uma Carta Constitucional produto do poder constituinte originário, como uma lei fundamental provida de supremacia, onde a vontade política do governante não pode se sobrepor à vontade da maioria constituinte incorporada à então Lei Fundamental. Por isso, de acordo com a doutrina clássica, o ato contrário à Constituição sofre de nulidade absoluta.

A contrariedade aos seus mandamentos acarreta a inconstitucionalidade formal ou material da lei. Inconstitucional é, portanto, todo ato normativo cujo conteúdo ou cuja forma contraponha-se, de modo expresso ou implícito, ao contemplado em dispositivo da Constituição vigente à época de sua edição.

Segundo a visão de Luigi Ferrajoli (2014), a legitimidade das normas é regulada por duas dimensões: a vigência no que tange à conformidade dos atos normativos com as normas que regulam sua formação e a validade, que, em se tratando de leis, equipara-se à constitucionalidade, dependendo da coerência com as normas substanciais sobre a sua produção. Portanto, trata-se de dois conceitos diferentes e independentes entre si, pois, enquanto a vigência, que guarda relação com a forma dos atos, encerra uma questão de subsunção entre as formalidades dos atos produtivos de normas e as normas formais sobre sua produção; a validade adequa-se ao significado, referindo-se a uma questão de coerência ou compatibilidade das leis produzidas com as normas de caráter substancial sobre a sua produção.

Neste seguimento, uma lei fundamental por vício material não é inexistente quando ingressa no âmbito jurídico, podendo, inclusive, obter 
aplicação efetiva. Entretanto, no que tange à validade, a norma inconstitucional pode encontrar impedimento por ferir a supremacia constitucional, que no plano da eficácia torna a lei inaplicável.

Em virtude da gravidade do vício, é inadmissível sua anulabilidade, isto é, que a inconstitucionalidade acarrete a sua nulidade, cujo reconhecimento tem caráter declaratório e não constitutivo, razão pela qual produz efeitos ex tunc, colhendo a lei desde a entrada no mundo jurídico. Por isso, é importante o magistrado, antes de aplicar a lei, verificar a sua validade, ou seja, sua compatibilidade com a Constituição. Ademais, a interpretação da lei, conforme a Constituição sancionada pela doutrina e jurisprudência, deve ter como objeto harmonizar o preceito legal com a Magna Carta sem que se altere o significado do texto normativo, evitando-se uma contradição insanável, devendo-se, por força da supremacia da Constituição, declarar a nulidade da norma inconstitucional.

Em observância à Constituição de 88 e às leis anteriores a ela como o Código de Processo Penal de 1941, há convergência entre o princípio da continuidade da ordem jurídica e o da supremacia da Constituição. Por isso, o primeiro princípio preserva a vigência e a eficácia da legislação anterior ao advento da Carta, evitando vácuos legislativos, e o segundo tem a finalidade de limitar a tentativa de preservação, determinando que só podem continuar vigendo as normas que possuírem harmonia com o novo Texto Magno. Segundo Gilmar Ferreira Mendes e Paulo Gustavo Gonet Branco (2017, p. 217). Neste caso, opera-se o fenômeno da recepção que corresponde a uma revalidação das normas que não desafiam materialmente a nova Constituição.

Nessa linha, mesmo artigos constitucionais que mantiveram a redação de preceitos da Constituição anterior, devem ser objeto de reinterpretação à luz dos fins e dos princípios instituídos pela nova ordem, ou seja, permanecerá em vigor e com validade quando houver concordância material (de conteúdo) com a novas normas constitucionais.

Por isso, o Código de Processo Penal (e outras leis ordinárias), elaborado na vigência da Constituição de 37, continua em vigor, e, devido à nova Ordem Constitucional de 1988, assinalou importantes alterações no processo penal brasileiro, a começar pela consagração do sistema acusatório, impondo ao juiz criminal a adoção de nova postura no curso da instrução probatória. Nesse contexto, merece a reflexão da vigência e validade dos dispositivos infraconstitucionais atinentes à atuação instrutória do magistrado. 


\subsection{A Constituição de 88 e sua incidência na atuação instrutória do juiz criminal}

Infelizmente podemos observar que a legislação processual penal não acompanhou a evolução constitucional, visto que o magistrado ignora a mudança da principiologia constitucional e continua a aplicar, sem qualquer juízo crítico, a norma infraconstitucional sem reconhecer, na sua interpretação, a força normativa do Texto Magno que se encontra em conformidade com o sistema acusatório.

A consagração de tal sistema pela Constituição Cidadã de 1988, implicaria a revogação dos artigos 168, 196, 209, 234, 242, em especial o 156 do CPP, o qual atribui poderes instrutórios ao juiz, não se aplicando neste caso de interpretação conforme a Constituição, por se tratar de incompatibilidade manifesta e insanável, característica do princípio inquisitivo, fundando um sistema nitidamente inquisitorial.

Em destaque, a nova redação do art. 156 do CPP, dada pela Lei ${ }^{\circ}$ $11.690 / 2008$, por se tratar de um ato normativo posterior à promulgação da Constituição Federal, trata-se de uma hipótese mais que evidente de inconstitucionalidade. Seus incisos I e II facultam a iniciativa instrutória do juiz, respectivamente, durante a investigação criminal e na fase processual, reforçando a adoção do sistema inquisitório, o qual não se harmoniza com o sistema processual penal eleito pela Magna Carta. Neste caso, cabe ao juiz assumir uma postura garantidora, como não ficando inerte às violações ou ameaças de lesão aos direitos fundamentais constitucionalmente consagrados no Estado Democrático de Direito. Nesse caso, antes de sobrevir a decisão do STF acerca da inviolabilidade do art. 156 do CP, competiria ao magistrado fazer valer a aplicação do poder de controle difuso de constitucionalidade, negando a aplicabilidade desta norma no caso concreto, em virtude de sua invalidade substancial.

Insta observar que a consagração constitucional do sistema acusatório impõe ao juiz uma atuação instrutória passiva, ou seja, sendo absolutamente vedados quaisquer poderes instrutórios. Durante a instrução probatória, compete ao magistrado a função de destinatário do material produzido e de garantidor dos direitos e garantias fundamentais (art. $5^{\circ}$ da CF), emitindo, assim, um juízo de valor proporcional aos meios de prova, aos meios de busca da prova, à idoneidade dos elementos de prova e 
à credibilidade das fontes, além de avaliar o resultado probatório por uma decisão motivada conforme o art. 98, X, da CF.

Por isso, o magistrado deve manter a imparcialidade, assumindo uma postura de "juiz-espectador" mantendo-se afastado da atividade probatória, fazendo jus à adoção constitucional do sistema acusatório, separando a condição de julgar e acusar, em respeito às "regras do jogo democrático", isto é, assegurando os direitos e garantias fundamentais do acusado.

\section{CONCLUSÃO}

Ao longo deste trabalho, podemos verificar que a principal finalidade do processo penal é a reconstrução de um fato pretérito, que funciona mediante a instrução probatória, sendo necessário o reconhecimento que o núcleo fundante incide sobre a gestão da prova. Nos sistemas processuais penais apresentados, o sistema acusatório (fundado pelo princípio acusatório) caracteriza-se pela figura do "juiz-espectador", isto é, separando a função de julgar e acusar, mantendo-se numa postura equidistante no curso do processo, visto que o Ministério Público é o órgão acusador, competente e estruturado que possui o ônus da acusação. A contrario sensu, o sistema inquisitório é regido pelo princípio inquisitivo que atribui ao magistrado o papel de gestor da prova, sendo este um juiz inquisidor.

No sistema acusatório, a prova deve ser produzida para construir o convencimento com o fim de formar a convicção do julgador. Nessa linha, o magistrado possui uma atividade recognitiva sendo necessário que entre o conhecimento do caso concreto e a sentença (fruto do seu convencimento), exista uma colheita dos elementos de convicção, a qual configura a instrução probatória. Nessa recognição, presente na fase instrutória do sistema acusatório, há uma barreira intransponível consubstanciada nos direitos e garantias fundamentais do denunciado, devendo o juiz, além de ser o destinatário do material colhido, impedir as violações a tais direitos.

Nesse sentido, a atuação do magistrado no sistema acusatório limita-se ao comando do princípio acusatório, possuindo este uma reserva da função jurisdicional, impedindo a atuação nas atividades típicas das 
partes (juiz-espectador), dentre as quais se inclui a proposição do material probatório. Por isso, há de se observar que o magistrado que exerce poderes instrutórios em razão da insuficiência das provas inseridas nos autos, cujo ônus compete à acusação (Ministério Público), desrespeita os princípios constitucionais da presunção de inocência (art. 50, LVII) e do in dubio pro reo, os quais impõem a absolvição do réu em caso de dúvida judicial, que nos dias atuais aparenta um comprometimento com a tese acusatória com base no "inexistente" e "popular" princípio do in dubio pro societate, o que implica uma violação ao princípio da imparcialidade.

Dessa forma, a iniciativa instrutória do magistrado justifica um sistema caracterizado pelo princípio inquisitivo, sob o pretexto da busca de uma utópica verdade absoluta, concentrando-se os mais amplos poderes nas mãos do juiz, com propósito de uma condenação a qualquer custo. Por outro lado, no sistema fundado pelo princípio acusatório imperam os princípios da presunção de inocência, do in dubio pro reo e da imparcialidade judicial, onde a prova é produzida como mecanismo de construção do convencimento do julgador, isto é, inadmitindo quaisquer poderes instrutórios ao juiz.

Na República Federativa do Brasil, há uma incoerência entre o sistema processual penal adotado pela Magna Carta Cidadã de 1988 e a legislação processual penal infraconstitucional de 1941, com características inquisitórias inspiradas no modelo fascista. A solução para este conflito legislativo seria mediante a observância e reconhecimento do princípio da supremacia da Constituição pelo intérprete, o que infelizmente é violado diariamente nos nossos tribunais.

Nessa linha, a consagração do sistema acusatório pelo Texto Magno, implica a revogação das normas infraconstitucionais que atribuam poderes instrutórios ao juiz, em especial o artigo 156 do CPP, por se tratar de ato normativo posterior à promulgação da Constituição, tendo este dispositivo uma evidente inconstitucionalidade material. Por isso, enquanto o Supremo Tribunal Federal não se posicionar acerca da inconstitucionalidade da matéria, compete ao magistrado valer-se do controle difuso de constitucionalidade, negando a aplicabilidade da norma em cada caso concreto por sua invalidade, separando a condição de julgar e acusar, em respeito às "regras do jogo democrático", isto é, assegurando os direitos e garantias fundamentais do acusado. 


\section{REFERÊNCIAS}

BECCARIA, Cesare. Dos delitos e das penas. 3. ed. 2015. São Paulo: CL EDIJUR.

FERRAJOLI, Luigi. Direito e razão: teoria do garantismo penal. 4. ed. rev. São Paulo: Revista dos Tribunais, 2014.

GRECO, Rogério. Sistema prisional: colapso atual e soluções alternativas. 3. ed. Niterói: Impetus, 2016.

LOPES JUNIOR, Aury. Direito Processual Penal. 12. ed. São Paulo. Saraiva. 2015.

LOPES JUNIOR, Aury. Direito Processual Penal. 14. ed. São Paulo. Saraiva. 2017.

MENDES, Gilmar Ferreira; BRANCO, Paulo Gustavo Gonet. Curso de Direito Constitucional. 12. ed. rev. e atual. São Paulo: Saraiva, 2017.

OLIVEIRA, Eugênio Pacelli de. Curso de processo penal. 5. ed. Belo Horizonte: Del Rey, 2005.

BRASIL. Decreto-Lei no 3.689, de 3 de outubro de 1941. Código de Processo Penal. Disponível em: <http://www.planalto.gov.br/ccivil_03/decreto-lei/Del3689.htm>. Acesso em: 23 nov. 2018.

PRADO, Geraldo. Sistema acusatório: a conformidade constitucional das leis processuais penais. 2 ed. Rio de Janeiro: Lumen Juris, 2001.

RANGEL, Paulo. Direito Processual Penal. 6 ed. Rio de Janeiro, Lumen Juris. 2002. 